\title{
Fourier Transform Infrared Spectroscopic Study of Rabbit Glue/Inorganic Pigments Mixtures in Fresh and Aged Reference Paint Reconstructions
}

Davide Pellegrini ${ }^{1}$, Celia Duce ${ }^{2}$, Ilaria Bonaduce ${ }^{2}$, Simona Biagi ${ }^{1}$, Lisa Ghezzi ${ }^{2}$, Maria Perla Colombini $^{2}$, Maria Rosaria Tine ${ }^{2}$ and Emilia Bramanti ${ }^{1 *}$

${ }^{1}$ National Research Council of Italy, C.N.R., Istituto di Chimica dei Composti Organo MetalliciICCOM- UOS Pisa, Area di Ricerca, Via G. Moruzzi 156124 Pisa (Italy)

${ }^{2}$ Dipartimento di Chimica e Chimica Industriale, Via Risorgimento 35, 56127 Pisa, Italy

*Corresponding author: Emilia Bramanti, National Research Council of Italy, C.N.R., Istituto di Chimica dei Composti Organo Metallici-ICCOM- UOS Pisa, bramanti@pi.iccom.cnr.it

Prepared for submission to Microchemical Journal, July $23^{\text {rd }} 2015$ 


\begin{abstract}
We studied the interactions of rabbit glue, a collagen-based proteinaceous binder, with azurite $\left(\mathrm{Cu}_{3}\left(\mathrm{CO}_{3}\right)_{2}(\mathrm{OH})_{2}\right)$, calcium carbonate $\left(\mathrm{CaCO}_{3}\right)$, hematite $\left(\mathrm{Fe}_{2} \mathrm{O}_{3} \cdot \mathrm{nH}_{2} \mathrm{O}\right)$, red lead $\left(\mathrm{Pb}_{3} \mathrm{O}_{4}\right)$ and cinnabar (HgS) by Fourier Transform Infrared Spectroscopy (FT-IR). The research was carried out on a set of paint reconstructions, which were analysed before and after artificial light ageing. A deconvolution of the amide I FT-IR absorption peak was performed with a written-in-house LabVIEW program to study the secondary structure of the glue.

The changes in the glue conformation highlighted that all the inorganic pigments interact with the proteinaceous binder. The conformational changes were correlated with a loss of stability of the collagen structure, especially after ageing, likely due to the interlayer coordination of metals salts and oxide with protein functional groups. These results were correlated with the lower thermal stability of the glue/pigment mixtures with respect to the pure glue, evidenced by Thermogravimetry (TG) and differential scanning calorimetry (DSC) analyses performed in a previous step of this work.
\end{abstract}

Keywords: animal glue, collagen, azurite, calcium carbonate, hematite and red lead, cinnabar, Fourier Transfrom Infrared Spectroscopy (FTIR). 


\section{Introduction}

Fourier-transform infrared spectroscopy (FT-IR) is a well-established technique to characterize organic and inorganic painting materials present in artworks [1], being non destructive, fast and low cost technique, and requiring minimum sample preparation [2]. Moreover, the use of different FT-IR configurations (e.g. ATR, DRIFT, PAS spectroscopies, FT-IR microspectroscopy, etc.) ensures high versatility in investigating both organic and inorganic materials in Cultural Heritage, for several purposes, such as diagnostic [1-6] and localization of materials in paint cross sections [712]. Infrared spectroscopy is also a fundamental tool to investigate the degradation and ageing of organic materials in Cultural Heritage. Among these, proteinaceous paint binders are particularly complex, given their composition and structure [1, 13-15].

FT-IR can be used to study proteins to gain molecular and conformational information. The spectral data are, indeed, interpreted in terms of the vibrations of the structural amide bond repeated unit, which give rise to nine characteristic IR absorption bands, namely amide A, B and I-VII [1619]. Among these, amide I and amide II bands are the two most prominent vibrational bands of the protein backbone, with amide I (1700-1600 $\left.\mathrm{cm}^{-1}\right)$ being the most sensitive one in terms of conformational information [20]. The amide I band is due almost entirely to the $\mathrm{C}=\mathrm{O}$ stretching vibrations of the peptide bonds and the frequencies arising from each component of this absorption are found to be closely correlated to the protein secondary structure [21]. The peak fitting procedure applied to the amide I absorption band provides, indeed, information about the various secondary motifs (e.g. helix, $\beta$-sheets, turns, random coils, etc.) and the contribution of each component to the secondary structure of the protein [22-25]. This approach was used to study proteinaceous paint binders, in order to investigate the interaction occurring between selected pigments and ovalbumin and casein and their changes with ageing [26].

Animal glues are the other commonly used proteinaceous binders in paintings. Animal glues are obtained by extraction and partial hydrolysis of collagen from animal hides and bones. Collagen in 
its natural state is water insoluble, while animal glues are soluble in hot water [27], although the solubility of animal glue decreases with ageing [28, 29].

In this work we study the interaction of pigments with animal glue. In particular we present the results of the study of the interaction of five pigments (azurite $\left(\mathrm{Cu}_{3}\left(\mathrm{CO}_{3}\right)_{2}(\mathrm{OH})_{2}\right)$, calcium carbonate $\left(\mathrm{CaCO}_{3}\right)$, hematite $\left(\mathrm{Fe}_{2} \mathrm{O}_{3} \cdot \mathrm{nH}_{2} \mathrm{O}\right)$, red lead $\left(\mathrm{Pb}_{3} \mathrm{O}_{4}\right)$ and cinnabar $\left.(\mathrm{HgS})\right)$ with rabbit glue binder and their chemical modification with ageing at molecular level by FT-IR spectroscopy. Analyses were carried out on model painting samples before and after artificial ageing under indoor light ageing. The results are discussed in terms of protein conformation changes due to the interaction with pigments and ageing. This study completes the previous investigation of proteinaceous binders and pigments $[27,30]$.

\section{Experimental Section}

\section{Chemicals and samples}

Paint reconstructions were prepared using rabbit glue (53921) purchased from Bresciani srl (Milan, Italy) in mixtures or alone, with azurite $\left(\mathrm{Cu}_{3}\left(\mathrm{CO}_{3}\right)_{2}(\mathrm{OH})_{2}\right)$, calcium carbonate $\left(\mathrm{CaCO}_{3}\right)$, hematite $\left(\mathrm{Fe}_{2} \mathrm{O}_{3}\right)$, red lead $\left(\mathrm{Pb}_{3} \mathrm{O}_{4}\right)$ and cinnabar $(\mathrm{HgS})$. The glue was dissolved in water and heated in a bain-marie until a clear/fluid solution was obtained. The pigment was mixed with the fluid binder in proportions that produced a paintable paste. The paint was then applied with a brush on glass slides for the microscope. A set made up of each typology of pigment/protein replica was analyzed before and after artificial indoor ageing in the Solarbox (see Apparatus and methods) and then stored at room temperature in the laboratory.

\section{Equipments}

FT-IR spectroscopy. Infrared spectra were recorded on a Perkin-Elmer Spectrum One FT-IR spectrophotometer, equipped with a universal attenuated total reflectance (ATR) accessory and a triglycine sulfate TGS detector. After recording the background spectrum, for each sample 128 
interferograms were recorded, averaged and Fourier-transformed to produce a spectrum with a nominal resolution of $4 \mathrm{~cm}^{-1}$. The spectra were run and processed by means of the Perkin-Elmer spectrum software and a written-in house LabVIEW program for peak fitting, respectively. Analyses were performed on the model samples before and after the artificial ageing.

Prior to curve processing, a straight baseline passing through the ordinates at 1800 and $1480 \mathrm{~cm}^{-1}$ was subtracted and spectra were normalized in the $1700-1600 \mathrm{~cm}^{-1}$ region. This approach was taken in order to avoid artefacts in absorptions near the limits of the region examined (1700 - 1600 $\mathrm{cm}-1)$. Then, the second derivatives of the amide I band of the spectra examined $\left(1700-1600 \mathrm{~cm}^{-1}\right.$ region) were analysed in order to determine the starting data (number and position of Gaussian components) required for the deconvolution procedure. The choice of the amide I band for structural analysis is due to the very low contribution of the amino acid side chain absorptions present in this region[31], and to its higher intensity with respect to other amide modes. On the basis of the infrared assignment of amide components, assuming that the extinction coefficient is the same for all the secondary structures, the secondary structure composition can be obtained from the FTIR spectra. The values for the percentages of the different secondary structures were estimated by expressing the amplitude value of the bands assigned to each of these structures as a fraction of the total sum of the amplitudes of the amide I components. While the general validity of the assumption above made about the extinction coefficients remains to be tested, the good correlation found between the secondary structure results obtained by FTIR approaches and x-ray crystallography indicated that this is a reasonable assumption [32].

Solarbox. The Solarbox (1500e RH), purchased from Erichsen (Germany), was used for artificially ageing the paint replicas. The exposure conditions were $720 \mathrm{~h}$ at $25 \circ \mathrm{C}, 50 \%$ relative humidity $(\mathrm{RH})$ and irradiance $550 \mathrm{~W} / \mathrm{m}^{2}$. A Soda-lime glass UV filter was used to simulate indoor exposure. Irradiation uniformity was guaranteed by a parabolic reflector chamber with the xenon lamp in the focus. 


\section{Results and discussion}

\section{FT-IR amide I peak fitting}

Figure 1 shows the comparison of the FT-IR spectra of glue, aged glue, glue/pigment and aged glue/pigment paint replicas in the $1750-850 \mathrm{~cm}^{-1}$ region.
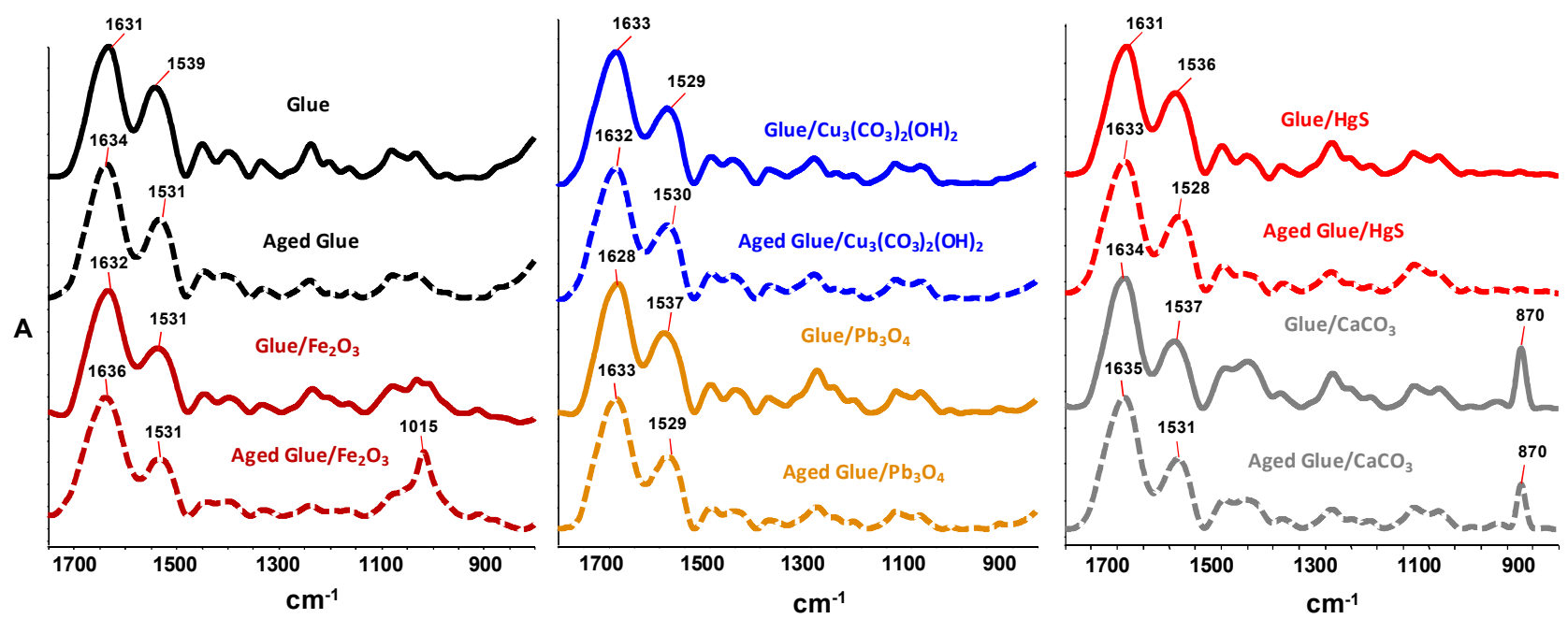

Figure 1. Comparison of the FT-IR spectra of glue, aged glue, glue/pigment and aged glue/pigment paint replicas in the $1750-850 \mathrm{~cm}^{-1}$ region.

A careful investigation of specific absorption bands is fundamental to obtain useful information about the interaction of pigments with collagen hydrolysate. The strong absorption bands in the range $1628-1636$ and $1528-1539 \mathrm{~cm}^{-1}$ were attributed to amide $\mathrm{I}(\mathrm{C}=\mathrm{O}$ stretching $)$ and amide $\mathrm{II}(\mathrm{CN}$ stretching and $\mathrm{NH}$ bending) of the glue. Absorption bands in the fingerprint region from 1450 to $1000 \mathrm{~cm}^{-1}$ were attributed to $\mathrm{CH}_{2}$ wagging, $\mathrm{CH}_{3}$ deformation, $\mathrm{C}-\mathrm{N}$ stretching and $\mathrm{C}-\mathrm{OH}$ stretching of the proteinaceous binder [33].

The FT-IR spectra of glue and aged glue paint replicas do not show significant differences, suggesting that the pure glue is stable during ageing. The addition of pigments to the pure glue induces a modification of the absorption bands shapes in the fingerprint region. Particularly, the FT-IR spectra of glue $/ \mathrm{CaCO}_{3}$ exhibit the characteristic absorption peak at $870 \mathrm{~cm}^{-1}(\mathrm{C}-\mathrm{O}$ stretching 
of $\left.\mathrm{CO}_{3}{ }^{2-}\right)$ and the other absorption peak features of carbonate in the fingerprint region (1500-1400 $\mathrm{cm}^{-1}$ ), which cover all protein characteristic absorptions except for the amide I band [26, 34].

The FT-IR spectra of aged glue/pigments show significant differences with respect to the unaged samples in the amide and fingerprint regions, in terms of number, frequencies and shapes of absorption bands. These differences can be ascribed to the interactions between the pigments and the proteinaceous binder, which induce a different behavior in the glue conformation after ageing. For example, in the FT-IR spectrum of the glue/hematite paint replicas, the band at $1015 \mathrm{~cm}^{-1}$, which is enhanced in aged sample, can be due to the interaction of iron metal center with the oxygen atoms of proline and hydroxyproline of collagen.

As stated above, different secondary structures of proteins (i.e. turns, antiparallel $\beta$-sheets, helix, intramolecular $\beta$-sheets, intermolecular $\beta$-sheets and random coils) contribute to the overall stretching of the carbonyl double bond (amide I) and a second derivative spectrum analysis provides information about the number and frequencies of the components [19]. Secondary structure motifs were estimated by expressing the amplitude of the bands, assigned to each structure as a fraction of the total sum of the amplitudes of the amide I components [35]. Figure 2 shows representative peak fitting results performed on pure glue, aged pure glue, glue/ $/ \mathrm{Fe}_{2} \mathrm{O}_{3}$ and aged glue $/ \mathrm{Fe}_{2} \mathrm{O}_{3}$ paint replicas. 


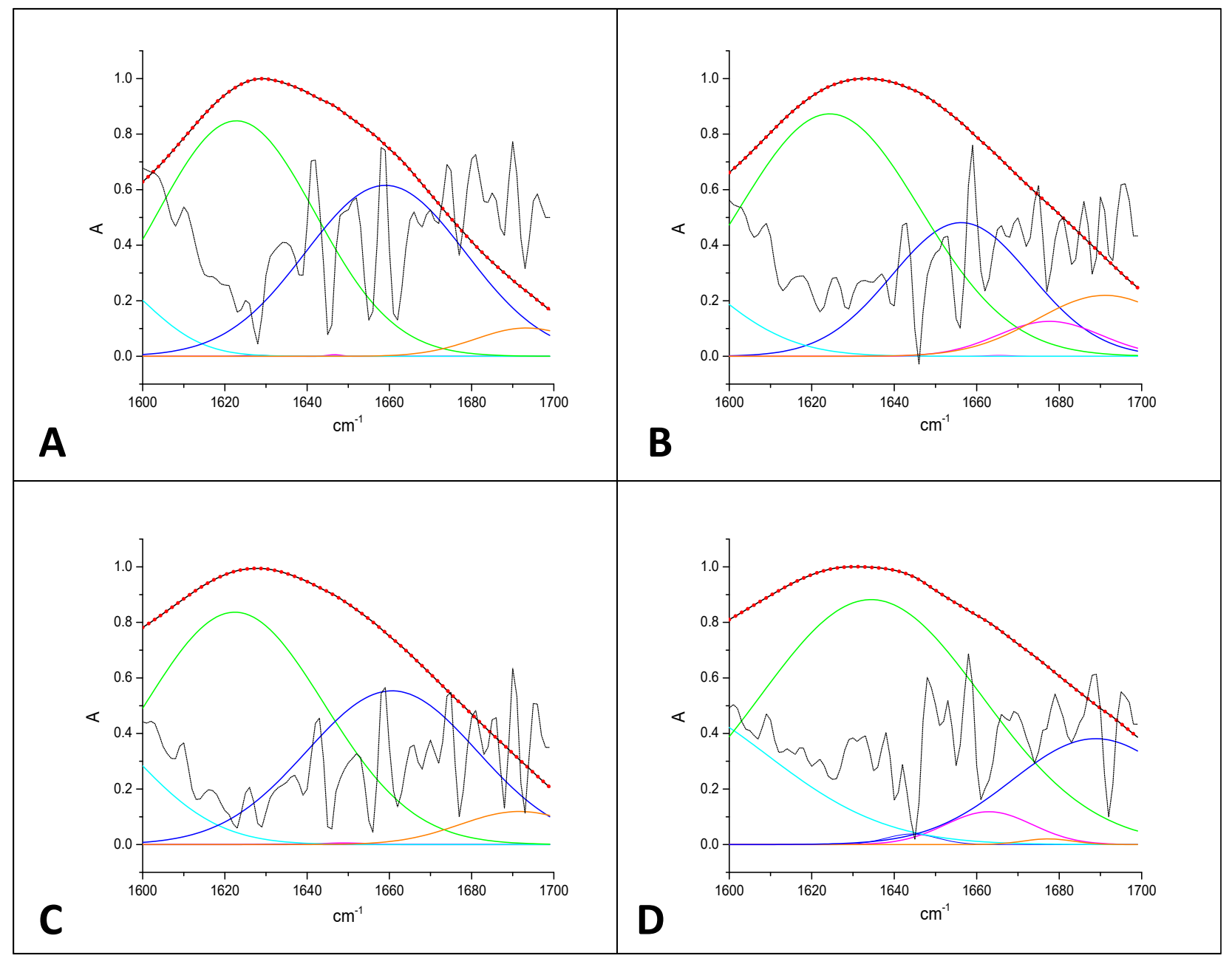

Figure 2. FT-IR spectra in the amide I region of (A) pure glue, (B) aged pure glue, (C) glue/ $\mathrm{Fe}_{2} \mathrm{O}_{3}$, (D) aged glue/ $\mathrm{Fe}_{2} \mathrm{O}_{3}$ paint replicas compared with the predicted spectra (bold dotted red line), resulted from the amide I peak fitting procedure. The black dashed lines represent the second derivative spectra. The colored lines correspond to the components of the amide I peak.

The frequency of the absorption bands due to each secondary structure of the protein, obtained from the peak fitting procedure described, was assigned according to the literature [20, 21, 36-38], namely $c a .1680 \mathrm{~cm}^{-1}$ to turns, $1690 \mathrm{~cm}^{-1}$ to antiparallel $\beta$-sheets, $1656 \mathrm{~cm}^{-1}$ to helix, $1630 \mathrm{~cm}^{-1}$ to intramolecular $\beta$-sheets, $1610 \mathrm{~cm}^{-1}$ to intermolecular $\beta$-sheets and $1648 \mathrm{~cm}^{-1}$ to random coils.

Table 1 shows the secondary structure percentage found in each samples analysed. Figure 3 shows the helix percentage in the unaged and aged samples. 
Table 1. Results of the deconvolution procedure applied to the amide I region of FT-IR spectra of unaged and aged glue paint replicas with and without pigments. The frequency $\left(\mathrm{cm}^{-1}\right)$ of each single Gaussian component and the correspondent \% (between brackets) are reported.

\begin{tabular}{|c|c|c|c|c|c|c|c|c|c|c|c|c|}
\hline Glue & Aged glue & $\begin{array}{c}\text { Glue/ } \\
\mathrm{Cu}_{3}\left(\mathrm{CO}_{3}\right)_{2}(\mathrm{OH})_{2} \\
\end{array}$ & $\begin{array}{c}\text { Aged glue/ } \\
\mathrm{Cu}_{3}\left(\mathrm{CO}_{3}\right)_{2}(\mathrm{OH})_{2} \\
\end{array}$ & $\begin{array}{c}\text { Glue/ } \\
\mathrm{CaCO}_{3}\end{array}$ & $\begin{array}{c}\text { Aged glue/ } \\
\mathrm{CaCO}_{3}\end{array}$ & $\begin{array}{l}\text { Glue/ } \\
\mathrm{Fe}_{2} \mathrm{O}_{3} \\
\end{array}$ & $\begin{array}{c}\text { Aged glue/ } \\
\mathrm{Fe}_{2} \mathrm{O}_{3} \\
\end{array}$ & $\begin{array}{l}\text { Glue/ } \\
\mathrm{Pb}_{3} \mathrm{O}_{4} \\
\end{array}$ & $\begin{array}{c}\text { Aged glue/ } \\
\mathrm{Pb}_{3} \mathrm{O}_{4}\end{array}$ & $\begin{array}{c}\text { Glue/ } \\
\text { HgS }\end{array}$ & $\begin{array}{c}\text { Aged glue/ } \\
\mathrm{HgS}\end{array}$ & Assignement \\
\hline $1623(54 \%)$ & $1624(51 \%)$ & $\begin{array}{l}1604(38 \%) \\
1622(12 \%)\end{array}$ & $\begin{array}{l}1614(25 \%) \\
1634(25 \%)\end{array}$ & $\begin{array}{l}1620(34 \%) \\
1639(23 \%)\end{array}$ & $\begin{array}{l}1616(29 \%) \\
1639(31 \%)\end{array}$ & $1622(55 \%)$ & $1634(62 \%)$ & $\begin{array}{c}1620(18 \%) \\
1633(2 \%)\end{array}$ & $1622(47 \%)$ & $\begin{array}{l}1620(35 \%) \\
1635(19 \%)\end{array}$ & $\begin{array}{l}1620(34 \%) \\
1641(23 \%)\end{array}$ & $\beta$-sheets \\
\hline \multirow[t]{2}{*}{$1659(39 \%)$} & $1656(28 \%)$ & $1652(38 \%)$ & $1653(21 \%)$ & $1662(33 \%)$ & $1660(18 \%)$ & $1661(36 \%)$ & $1663(11 \%)$ & $1651(68 \%)$ & $1655(33 \%)$ & $\begin{array}{l}1651(18 \%) \\
1667(28 \%)\end{array}$ & $\begin{array}{c}1652(3 \%) \\
1663(25 \%)\end{array}$ & Helix \\
\hline & $1678(8 \%)$ & & $1671(17 \%)$ & & $1676(22 \%)$ & & & & $1677(4 \%)$ & & $1684(15 \%)$ & $\beta$-turns \\
\hline $1693(7 \%)$ & $1691(13 \%)$ & $1689(12 \%)$ & $1687(12 \%)$ & $1687(10 \%)$ & & $1692(9 \%)$ & $1689(27 \%)$ & $1689(12 \%)$ & $1688(16 \%)$ & & & $\begin{array}{c}\text { Antiparallel } \\
\beta \text {-sheets }\end{array}$ \\
\hline
\end{tabular}




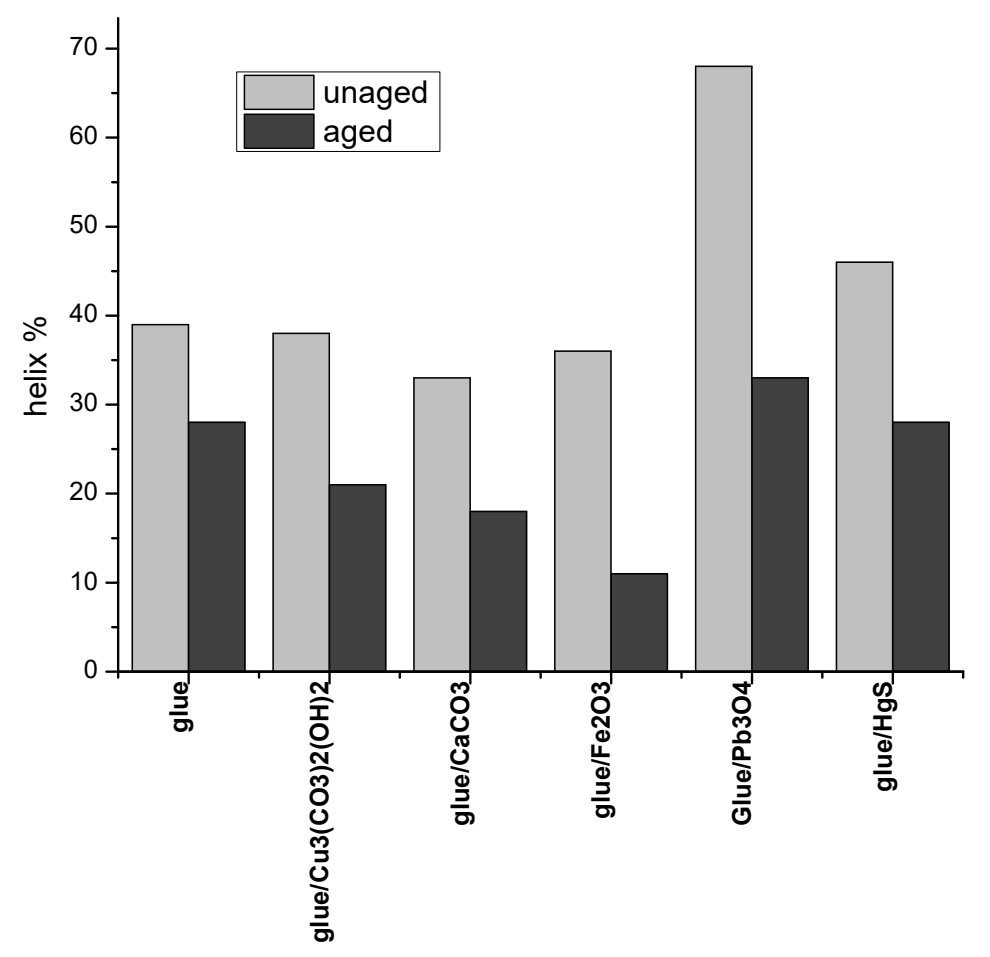

Figure 3. Helix percentage in the unaged and aged samples.

The glue paint replica has $39 \%$ helix percentage, by far lower than helix percentage found in native collagen [37]. This is because the collagen in the products commonly employed as paint binders is partially hydrolysed.

The presence of the pigment in glue paint replicas induces a conformational re-arrangement in almost all unaged samples, and even more in aged paint replicas.

The helix components remained unchanged in unaged glue/pigment samples except for unaged glue $/ \mathrm{Pb}_{3} \mathrm{O}_{4}$ and glue/HgS samples for which we observed a significant increase of the helix percentage. In glue/HgS samples the helix components was also splitted into a low frequency (1651, 18\%) and a high frequency component $(1667,28 \%)$.

In all the aged samples we observed a decrease in the percentage of helices (Figure 3) and a corresponding increase of $\beta$ structures. In particular, in the case of the aged hematite paint replicas, the relative percentage of helices was found to be the lowest among all the samples, suggesting a 
less stable structure of the glue. We recently found, indeed, that the helix content in collagen is correlated with its thermal stability [39]. This hypothesis is confirmed by the thermoanalytical measurements performed on the sample paint replicas [27]. In particular, thermogravimetry (TG) and differential scanning calorimetry (DSC) indicated a decrease of the thermal stability in all the pigmented samples, compared to the pure glue samples, and in all the aged samples. The highest decrease in helices observed in the aged hematite sample corresponds, indeed, to the lowest thermal stability found among all the aged samples.

In many cases of unaged and aged glue/pigment samples we also observed the splitting of the $\beta$ sheet component at $1623 \mathrm{~cm}^{-1}$ into two components at higher and lower frequencies, except for the glue/ $\mathrm{Fe}_{2} \mathrm{O}_{3}$ paint replica. The splitting of the components assigned to the same secondary structure suggests a possible change in the hydration state of the structure and/or the interaction of part of this structure with the pigment [40].

These results suggested the idea that pigments strongly interact with collagen hydrolysate primarily by electrostatic forces and by the coordination of metal centers with the strongly polar amino acids residues of collagen (Pro, Hyp, Asp, Glu, Lys, Asn, Gln). This may avoid the hydrogen bonding cross-linkage, important for the stabilization of helix secondary structures of collagen fibers. Pigments stabilize, instead, the $\beta$-sheet structures. However, their intercalation among collagen fibers gives a global lower thermal stability. We can hypothesize that the pigment salts and oxides located between beta sheets or between helices interfer with the mutual interaction of collagen fibers, thus inducing a destabilization of the protein structure [13] [41-43].

Despite the big differences among the structure of collagen hydrolysate and ovalbumin (OVA) and casein, an analogous behavior was observed for FTIR and TG study of OVA and casein paint replicas with $\mathrm{HgS}$ [30] and the other inorganic pigments $\left(\mathrm{Pb}_{3} \mathrm{O}_{4}, \mathrm{Fe}_{2} \mathrm{O}_{3}, \mathrm{CaCO}_{3}\right.$ and $\left.\mathrm{Cu}_{3}\left(\mathrm{CO}_{3}\right)_{2}(\mathrm{OH})_{2}\right)$ [26]. The interaction of OVA and casein with the inorganic pigments gave a 
decrease of their thermal stability as well as the increase of $\beta$-sheet content. Also for OVA and casein we hypothesized that pigments intercalate between protein molecules, producing a partial disruption of the protein-protein intermolecular interaction.

However during ageing, in casein/pigment paint replicas we observed the complete disappearance of intermolecular $\beta$-sheets, the increase of intramolecular $\beta$-sheets and random coil. In OVA paint replicas we observed the formation of new intermolecular $\beta$-sheets and the increase of their thermostability.

\section{Conclusions}

The results of the deconvolution analysis of the amide I FT-IR absorption band of glue/pigment paint replicas were employed to determine the effect of the addition of pigments in the conformation of the proteinaceous binder. Pigments, by interacting with the polar amino acids residues of collagen, and ageing cause changes of the secondary structure of the glue. This interaction, mostly evident after ageing, results into a decrease of helices and an increase of beta turns and antiparallel $\beta$-sheets. The lower thermal stability of the glue/pigment mixtures with respect to the pure glue recently evidenced by TG and DSC measurements confirmed that the observed conformational change is correlated with a loss of stability of collagen structure, likely due to the interlayer coordination of metals salts and oxide with protein functional groups.

These results agree with previous studies performed on OVA and casein $[26,30]$ and are conclusive of the study of the interactions of inorganic pigments with the proteinaceous binders most commonly employed in ancient paintings.

\section{ACKNOWLEDGMENTS}


This work was supported by PRIN 2008 (Project No 2008XXAMZT) and PRIN 2010/2011 (Project No. 2010329WPF) funding from the Italian Ministry of University and Research.

\section{REFERENCES}

[1] E. Manzano, N. Navas, R. Checa-Moreno, L. Rodriguez-Simon, L.F. Capitan-Vallvey, Preliminary study of UV ageing process of proteinaceous paint binder by FT-IR and principal component analysis, Talanta, 77 (2009) 1724-1731.

[2] E. Marengo, M.C. Liparota, E. Robotti, M. Bobba, Monitoring of paintings under exposure to UV light by ATR-FT-IR spectroscopy and multivariate control charts, Vibrational Spectroscopy, 40 (2006) 225-234.

[3] N. Navas, J. Romero-Pastor, E. Manzanoa, C. Cardell, Benefits of applying combined diffuse reflectance FTIR spectroscopy and principal component analysis for the study of blue tempera historical painting, Analytica Chimica Acta, 630 (2008) 141-149.

[4] G. Musumarra, M. Fichera, Chemometrics and cultural heritage, Chemometrics and Intelligent Laboratory Systems, 44 (1998) 363-372.

[5] E. Marengo, M. Cristina Liparota, E. Robotti, M. Bobba, Multivariate calibration applied to the field of cultural heritage: Analysis of the pigments on the surface of a painting, Analytica Chimica Acta, 553 (2005) 111-122.

[6] F. Casadio, L. Toniolo, The analysis of polychrome works of art: 40 years of infrared spectroscopic investigations, Journal of Cultural Heritage, 2 (2001) 71-78.

[7] I. Bonaduce, J.J. Boon, An integrated mass spectrometric and molecular imaging analytical approach to identify and localise constituents in paintings applied to gilded multilayer structures from 14th to 16th C works of art in: R. Signpost (Ed.) New Trends in Analytical, Environmental and Cultural Heritage Chemistry Kerala, 2008, pp. 389-423.

[8] J.J. Boon, E.S.B. Ferreira, K. Keune, Microsc. Microanal., 11 (2005) 1370.

[9] J.J. Boon, K. Keune, J. Zucker, Microsc. Microanal., 11 (2005) 444.

[10] A. Lluveras-Tenorio, A. Andreotti, I. Bonaduce, S. Boularand, M. Cotte, J. Roqué, M.P. Colombini, M. Vendrell-Saz, Mass Spectrometric and Synchrotron Radiation Based Techniques for the Identification and Distribution of Painting Materials in Samples From Paints of Josep Maria Sert, Chemistry Central Journal, 6 (2012) 45.

[11] M. Cotte, J. Susini, V.A. Solé, Y. Taniguchi, J. Chillida, E. Checroun, P. Walter, Applications of synchrotron-based micro-imaging techniques to the chemical analysis of ancient paintings, J. Anal. At Spectrom, 23 (2008) 820-828.

[12] S. Prati, F. Rosi, G. Sciutto, R. Mazzeo, D. Magrini, S. Sotiropoulou, M. Van Bos, Evaluation of the effect of six different paint cross section preparation methods on the performances of Fourier Transformed Infrared microscopy in attenuated total reflection mode, Microchemical Journal, 103 (2012) 79-89.

[13] J. Romero-Pastor, N. Navas, S. Kuckova, A. Rodríguez-Navarro, C. Cardell, Collagen-based proteinaceous binder-pigment interaction study under UV ageing conditions by MALDI-TOF-MS and principal component analysis, Journal of Mass Spectrometry, 47 (2012) 322-330.

[14] I.C.A. Sandu, C. Luca, I. Sandu, V. Vasilache, M. Hayashi, Authentication of the ancient easel paintings through materials identification from the polychrome layers - II. Analysis by means of the FT-IR spectrophotometry, Revista De Chimie, 59 (2008) 384-387.

[15] I.C.A. Sandu, V. Vasilache, I. Sandu, C. Luca, M. Hayashi, Authentication of the Ancient Easel-paintings through Materials Identification from the Polychrome Layers III. Cross - section Analysis and Staining Test, Revista De Chimie, 59 (2008) 855-866.

[16] B.C. Smith, Fundamentals of Fourier Transform Infrared Spectroscopy Boca Raton, Florida, 1996. 
[17] S. Krimm, J. Bandekar, Vibrational Spectroscopy and conformation of peptides, polypeptides, and proteins, Adv. Protein Chem., 38 (1986) 181-364.

[18] W.K. Surewicz, H.H. Mantsch, New insight into protein secondary structure from resolution-enhanced infrared spectra, Biochim. Biophys. Acta, 952 (1988) 115-130.

[19] H. Susi, D.M. Byler, Resolution-enhanced fourier transform infrared spectroscopy of enzymes, Methods Enzymol, 130 (1986) 290-311.

[20] H.D. Barth, E.A. Zimmermann, E. Schaible, S.Y. Tang, T. Alliston, R.O. Ritchie, Characterization of the effects of $x$-ray irradiation on the hierarchical structure and mechanical properties of human cortical bone, Biomaterials, 32 (2011) 8892-8904.

[21] J. Kong, S. Yu, Fourier Transform Infrared Spectroscopic Analysis of Protein Secondary Structures, Acta Biochimica et Biophysica Sinica, 39 (2007) 549-559.

[22] B. de Campos Vidal, M.L.S. Mello, Collagen type I amide I band infrared spectroscopy, Micron, 42 (2011) 283-289.

[23] S.Y. Venyaminov, N.N. Kalnin, Quantitative IR spectrophotometry of peptide compounds in water $\left(\mathrm{H}_{2} \mathrm{O}\right)$ solution. I. Spectral parameters of amino acid residue absorption bands Biopolymers, 30 (1990) 1243-1257.

[24] S.Y. Venyaminov, N.N. Kalnin, Quantitative IR spectrophotometry of peptide compounds in water $\left(\mathrm{H}_{2} \mathrm{O}\right)$ solution. II. Amide absorption bands of polypeptide and fibrous protein in a- b- and random coil conformations, Biopolymers, 30 (1990) 1259-1271.

[25] N.N. Kalnin, I.A. Baikalov, S.Y. venyaminov, Quantitative IR spectrophotometry of peptide compunds in water $\left(\mathrm{H}_{2} \mathrm{O}\right)$ solution. III. Estimation of the protein secondary structurel, Biopolymers, 30 (1990) 1273-1280.

[26] C. Duce, E. Bramanti, L. Ghezzi, L. Bernazzani, I. Bonaduce, M.P. Colombini, A. Spepi, S. Biagi, M.R. Tine, Interactions between inorganic pigments and proteinaceous binders in reference paint reconstructions, Dalton Transactions, 42 (2013) 5975-5984.

[27] L. Ghezzi, C. Duce, L. Bernazzani, E. Bramanti, M.P. Colombini, M.R. Tine, I. Bonaduce, Interactions between inorganic pigments and rabbit glue in reference paint reconstructions, Journal of Thermal Analysis and Calorimetry, in press (2015).

[28] M.P. Colombini, A. Andreotti, I. Bonaduce, F. Modugno, E. Ribechini, Analytical Strategies for Characterizing Organic Paint Media Using Gas Chromatography/Mass Spectrometry, Accounts of Chemical Research, 43 (2010) 715-727.

[29] G. Ranalli, G. Alfano, C. Belli, G. Lustrato, M.P. Colombini, I. Bonaduce, E. Zanardini, P. Abbruscato, F. Cappitelli, C. Sorlini, Biotechnology applied to cultural heritage: biorestoration of frescoes using viable bacterial cells and enzymes, Journal of Applied Microbiology, 98 (2005) 73-83.

[30] C. Duce, L. Ghezzi, M. Onor, I. Bonaduce, M. Colombini, M. Tine', E. Bramanti, Physico-chemical characterization of protein-pigment interactions in tempera paint reconstructions: casein/cinnabar and albumin/cinnabar, Anal Bioanal Chem, 402 (2012) 2183-2193.

[31] Y.N. Chirgadze, O.V. Fedorov, N.P. Trushina, Biopolymers 14 (1975) 679-694.

[32] E. Bramanti, E. Benedetti, Biopolymers, 38 (1996) 639-653.

[33] Q. Wang, W. Sanad, L.M. Miller, A. Voigt, K. Klingel, R. Kandolf, K. Stangl, G. Baumann, Infrared imaging of compositional changes in inflammatory cardiomyopathy, Vibrational Spectroscopy, 38 (2005) 217-222.

[34] C. Duce, V. Della Porta, M.R. Tiné, A. Spepi, L. Ghezzi, M.P. Colombini, E. Bramanti, FTIR study of ageing of fast drying oil colour (FDOC) alkyd paint replicas, Spectrochimica Acta Part A: Molecular and Biomolecular Spectroscopy, 130 (2014) 214-221.

[35] E. Bramanti, C. Ferrari, V. Angeli, M. Onor, R.E. Synovec, Characterization of BSA unfolding and aggregation using a single-capillary viscometer and dynamic surface tension detector, Talanta, 85 (2011) 2553-2561.

[36] S. Monti, E. Bramanti, V. Della Porta, M. Onor, A. D'Ulivo, V. Barone, Interaction of collagen with chlorosulphonated paraffin tanning agents: Fourier transform infrared spectroscopic analysis and molecular dynamics simulations, Phys. Chem. Chem. Phys., 15 (2013) 14736-14747.

[37] M.A. Bryan, J.W. Brauner, G. Anderle, C.R. Flach, B. Brodsky, R. Mendelsohn, FTIR Studies of Collagen Model Peptides: Complementary Experimental and Simulation Approaches to Conformation and Unfolding, Journal of the American Chemical Society, 129 (2007) 7877-7884. 
[38] T.L. Sellaro, D. Hildebrand, Q. Lu, N. Vyavahare, M. Scott, M.S. Sacks, Effects of collagen fiber orientation on the response of biologically derived soft tissue biomaterials to cyclic loading, Journal of Biomedical Materials Research - Part A, 80 (2007) 194-205.

[39] D. Pellegrini, M. Corsi, M. Bonanni, R. Bianchini, A. D'Ulivo, A. Bramanti, Study of the interaction between collagen and naturalized and commercial dyes by Fourier Transform Infrared Spectroscopy and Thermogravimetric Analysis, Dyes and Pigments, in press (2015).

[40] A. Barth, Infrared spectroscopy of proteins, Biochimica et Biophysica Acta (BBA) - Bioenergetics, 1767 (2007) 1073-1101.

[41] D. Pellegrini, M. Corsi, M. Bonanni, R. Bianchini, A. D'Ulivo, E. Bramanti, Study of the interaction between collagen and naturalized and commercial dyes by Fourier Transform Infrared Spectroscopy and Thermogravimetric Analysis, Dyes and Pigments, (2014).

[42] J.H. Muyonga, C.G.B. Cole, K.G. Duodu, Fourier transform infrared (FTIR) spectroscopic study of acid soluble collagen and gelatin from skins and bones of young and adult Nile perch (Lates niloticus), Food Chemistry, 86 (2004) 325-332.

[43] W. Friess, G. Lee, Basic thermoanalytical studies of insoluble collagen matrices, Biomaterials, 17 (1996) 2289-2294. 